\title{
Staged Representations of Négritude: Aboriginality and White Supremacy in Jane Harrison's Stolen
}

\author{
Rania Mohamed Rafik Abdel Fattah Khalil* \\ rania.khalil@bue.edu.eg
}

\begin{abstract}
Early performances of indigeneity in Australian theatre reveal an underpinning ideology of white European settler control and emphasise the shared beliefs which validate white dominance over the real and the imagined non-white counterparts. This ideology of power, staged through theatrical performances, reflected and supported the actual discriminatory practices against Aborigines in the different spheres of everyday life in Australia. In the early stages, performances were not mere adaptations of the local conditions, but rather a discourse taking part in the colonisation of Aboriginal Australians. This article studies the impact of the European settler State policies in Australia in Jane Harrison's Stolen (1998). The paper examines the severe ramifications of colonial practices such as assimilation, discrimination and racism on modern day Aboriginal Australians, particularly the Stolen Generation. Within a theoretical framework that rests on Léopold Sédar Senghor's and Aimé Césaire's notion of Négritude, the study analyzes the staged representations of blackness, Aboriginality and white supremacy in the play. The analysis further endeavors to show how the playwright renegotiates past experiences of pain as a means for modern day acceptance of the inevitable hybridity that results from contact between Aborigines and white Australia and the role Aborigine theatre has played within post-colonial discourse. Directed by Wesley Enoch, and written by Jane Harrison, Stolen, remains one of the most significant first Australian drama performances written and directed by Aboriginal Australians.
\end{abstract}

Keywords: Négritude, Stolen, Aboriginal Australian Theatre, Jane Harrison, White Supremacy

\footnotetext{
* Department of English Language and Literature, Faculty of Arts and Humanities, The British University in Egypt (BUE)
} 


\section{Introduction}

Early performances of indigeneity in Australian theatre reveal an underpinning ideology of white European settler control and emphasise the shared beliefs which validate white dominance over the real and the imagined non-white counterparts. This ideology of power, staged through theatrical performances, reflected and supported the actual discriminatory practices against Aborigines in the different spheres of everyday life in Australia. In the early stages, performances were not mere adaptations of the local conditions, but rather a discourse taking part in the colonisation of Aboriginal Australians.

Colonial settlement has denied Aboriginal Australians the cultural respect and the right to live within their traditions on their own land for over two hundred years. They have been massacred, forcibly removed, and enslaved. Women have been violated and children kidnapped from their families. Twentieth Century history has been equally brutal by eliminating Aborigines from Australian history. In 1968, William Stanner an anthropologist highlighted the depiction of the Aborigines as a dying race in the face of progress, this further emphasised the silence around their trauma under colonisation. Government policies provided the main framework that legalised the separation of Aboriginal families and discriminatory practices under the misnomer of civilisation and protection. In parallel, white women played a significant role in the reinforcement of colonial-settler measures, 
a role often not fully elaborated on in scholarly work. Playwrights of non-Aboriginal origins had also aided in the erasure of the Aboriginal heritage. Eradication policies enforced on Aborigines were successful through the erasure of cultural difference by assimilation. The United Nations Declaration on the Rights of Indigenous Peoples, in 2007, acknowledged the Aborigines' right to their land and the respect deemed necessary for their culture and traditions.

Maryrose Casey (2004) in her book Creating Frames: Contemporary Indigenous Theatre 1967-1990, explains that Aboriginal playwrights have in recent years been able to demonstrate their culture, relate the history of their Australian heritage, as well as advocate for action against racism on the theatre stage. Ignorance about Aboriginal cultures among the majority of white Australians had led to racial abuse and prejudices. These were often compounded by the heinous effects of colonialism often indescribable. Hence, performing on the theatre stage for Aboriginal performers not only communicated their heritage, but became a political act. This consequently, renders theatre the ideal vehicle for communicating the visual and the vocal to constitute the unspeakable be it abuse or that which cannot be uttered.

Mainstream Australian theatre has often staged representations of the invented archetype of the Aboriginal Australian colonial subject in images akin to savages; at the same time, the European 
Imperial system, has, in contrast, been represented on the theatre stage as cognitive and intellectual. This understanding is especially relevant because the effects of colonialism have extended to permeate many aspects of the lives of modern-day Aboriginal Australians. Situated in this context, the study of the dramatic text, Stolen is of significance as we continue to witness racism across different parts of the world.

\section{Stolen}

Jane Harrison's Stolen (1998) is an innovative act of rewriting the lived experiences of Aboriginal Australian removed children. Stolen, traces the lives of five Aboriginal children removed from their families under assimilation; an official Australian government policy that ruptured family bonds. The play documents the ramifications of colonial-settler policies on Aborigines highlighting, the discrimination and abuse experienced by the removed children and the impact that racism and white supremacy have had on their adult lives.

The play subverts all purposes that justify colonial domination by defying the preset concept that Aboriginal Australians are simple black bodies that lack the ability to be verbally articulate. The stage characters reveal the invisible restrictive behavioural codes inflicted on them by the dominant culture that separates on the foundation of race and at times on the basis of race and gender. The non-linear play is a series of interlocked yet stand- 
alone short scenes that reveal the Aborigines' experiences through storytelling in a non-conventional episodic form; the play culminates with the adult characters sharing their own personal experiences of fear, persecution and anguish.

In 1993, Jane Harrison was commissioned by the Ilbijerri Aboriginal and Torres Strait Islander Theatre to write a play representing the experiences of the removed children or as they have become commonly known as the Stolen Generation. The play displays the ongoing devastating effects on generations of Aboriginal people physically, psychologically and culturally. Stolen premiered in 1998 at the Melbourne International Festival. The play toured Australia, the UK, Hong Kong and Japan. Jane Harrison's Stolen is a vital dramatic text for Australian Theatre, dramatising the anguish, persecution and fear lived by the stolen children and their families.

\section{Literature Review}

Jane Harrison's drama performance Stolen directed by Enoch was reported by him as a play "that helped to change the course of history" (Enoch,2007, p.vii). Previous scholarly work solely focused on Jane Harrison's Stolen includes S. Devika's (2019) "Trauma of the Stolen Generation in Jane Harrison's Stolen," Shukry's (2019) Harrison's Stolen: Addressing Aboriginal and Indigenous Islanders Human Rights; Sharmila's (2016) Twinge of Being Stolen in Jane Harrison's Stolen; Emma Hughes' (2015) 
Maternal Practice and Maternal Presence in Jane Harrison's Stolen; Stolen Children, Invisible Mothers and Unspeakable Stories: The Experiences of Non-Aboriginal Adoptive and Foster Mothers of Aboriginal Children (2010) by Denise Cuthbert; Devi Kamala's The Plight of Stolen Generation in Jane Harrison's Stolen, an Australian Aboriginal play (2009); and Hilary Glow's Recent Indigenous Theatre in Australia (2006). At the same time, the most notable published work on theatre and négritude is Femi Osofisan's (1999), Theatre and the Rites of "Post- Négritude" Remembering, it tackles the reaffirmation of cultural rites and the reinscription of racial identity on the pages of history books. Scholarly publications on Jane Harrison's Stolen, to date have not examined the play through the lens of Négritude.

This paper analyzes the Aborigine experience in Harrison's Stolen through the theoretical framework of the Négritude movement. The current study aims to highlight how the underpinning foundations of the Négritude movement echo the efforts of Aborigines in Australia in their attempt to thwart negative representations of Blackness embedded within the European settler imagination. It also examines the confrontation of the notion of absence as a means to eradicate aboriginality. The analysis of the play Stolen, within this theoretical framework, examines the Aboriginal Australian experiences of being black and its repercussions on removed children under an oppressive colonial system. The paper aims to show that Stolen is about 
identity formation in the right context. In setting the boundaries of this study, it must be clarified that this is only one aspect of the Aboriginal Australian experience that is being investigated. This is a departing point for future research and not an endpoint in itself; this is one possible interpretation of Harrison's text.

\section{Aim of the Paper}

This paper examines the impact of the European settler State policies in Australia in Jane Harrison's Stolen (1998). The paper attempts to analyse the severe ramifications of colonial practices such as assimilation, discrimination and racism on modern day Aboriginal Australians, particularly the Stolen Generation. Within a theoretical framework that rests on Léopold Sédar Senghor's and Aimé Césaire's notion of Négritude, the study analyzes the staged representations of Blackness, Aboriginality and white supremacy in the play. An inductive reading of Jane Harrison's performance text Stolen (1998), excavates the voices of the marginalised and those that have been silenced for decades from the discussions. The analysis further endeavors to show how the playwright renegotiates past experiences of pain as a means for modern day acceptance of the inevitable hybridity that results from contact between Aborigines and white Australia and the role Aborigine theatre has played within post-colonial discourse. The analysis nods to what has previously been published on Stolen and engages with the key literature to present the space into which 
this study falls. Directed by Wesley Enoch, and written by Jane Harrison, Stolen, remains one of the most significant first Australian drama performances written and directed by Aboriginal Australians.

\section{Theoretical Framework- Negritude}

Europe for centuries has affirmed its identity through binary relations to others. Newly discovered geographical spaces such as Australia meant that the natives of these lands would be reinscribed in European discourse. Negative representations of Blackness in mainstream media, culture, literature and theatre were deeply embedded within the European beliefs and imagination. The depiction of the barbaric other led to the rise of racism against Aboriginal Australians. The analysis in this paper deals with the Aboriginal Australian experiences of being black under an oppressive colonial system. The theories on which this study draws upon are postcolonialism and the Négritude movement.

Négritude is a "reactionary and revolutionary response to colonialism" (Bird, 2019, p.85). It is an artistic, cultural and political movement which originated in the 1930s in Paris among the West-African and Caribbean diaspora. Négritude at its core is the rehumanisation of black people, a return of their humanity which they have been denied for centuries under colonialism (Ahluwalia, 2002, p.20). Edward Said (1993) defines Négritude 
as "reclaiming one's past" by assessing the relationship between the "colonizer and the colonized" (p.275). Black voices, historically, have been silenced both politically and artistically under colonialism. Négritude in this sense, recognises that the aesthetic output is a cultural response to the political and a way for black individuals to explain and interpret their value in the universe (Barrend van Dyk Van Kiekerk, 1970, p.100). Négritude, not only defined what it meant to be Black but explained it as "An act of self-discovery standing against the negative backdrop of the colonial experience" (Bird, 2019, p. 88). Arthur Ripstein (2009) further points out that the oppressive conditions imposed on the colonised nations by the colonisers are what gave rise to the Négritude movement. That, however, is not to imply that Négritude is of Western origins, but rather that its core philosophical underpinnings were grounded on a need to react to colonial oppression and the domination of individuals against their will.

One of the key founders of the movement Léopold Sédar Senghor, believed that all black people had the right to define themselves rather than be defined. According to Aimé Césaire, an activist of the Négritude movement, it was the communal effort of the black people to appropriate the term négre and overcome the negative implications of backwardness imposed on it by the colonisers. Négritude drew on the argument that the colonised were limited by those who maintained the power. Mbembe (2017) 
highlights that the Négritude movement's "function was to save from total decay what had been condemned to insignificance" (p.13). The value of the movement lies in it being multifaceted, which emphasises its role as a form of expression as Duncan Bell (2010) argues. Bell (2010) points out that "colonialism forces the people it dominates to ask themselves repeatedly 'in reality, who am I"' (p.7) and according to its underpinning philosophy, Négritude has aided in answering that question.

At the same time, scholars such as Stephen Howe (1999) and Barrend van Dyk (1970) point out that the definition of Black differs according to individual experiences and hence interpretations differ in their analysis of what it feels like to be a Black person. The movement however is not a notion without critics. Franz Fanon (1965) criticised the limiting potential of the movement in its expectation to find a communal definition of what it meant to be Black neglecting the significance of the different experiences and backgrounds of black people.

According to Bird (2019), Négritude was celebrated as a revolutionary emancipatory movement initiated by Senghor and Césaire, and criticised by Franz Fanon for "enslaving Black people within the shackles of an already defined image of the Black individual" (p.92). The movement's value lies in what Robert W. July (1987) summarises as the "celebration of black culture regardless of the fact that many differences existed among peoples of the different nations and continents. It was a whole 
movement ... [a]gainst the European's sense of superiority and scepticism, there had to be self-assertion, equal and opposite" (p.216). In principle, the Négritude movement rested upon the shared experiences of individuals' and groups' suffering at the hands of oppressors and colonisers. It must be clarified that whilst Fanon condemned the movement, it was still valued for enlightening Black individuals on how to emancipate themselves from domination and oppression. The three father figures of the Négritude movement are Léopold Sédar Senghor, Aimé Césaire and Léon Damas. Each of the three activists had a different stance. Senghor founded the movement and authored the texts that discussed its value, Césaire, educated in Paris, started with Senghor and Damas the paper L'Etudiant Noir. L'Etudiant Noir is referred to widely as the origin of the Négritude movement (Bird, 2019).

An analysis of the Aborigine experience of racism and the impact of colonialism in Harrison's Stolen, within the foundational principles of Négritude, gives the paper a personalised understanding of Blackness. Blackness is linked to the political, cultural and social repercussions on an individual who exists in a "community that has been consistently devalued, degraded, marginalized, and silenced over a long period of time" (Bird, 2019, p. 96). The paper will attempt to show through the notion of Négritude how the playwright, in Stolen, "responded to these feelings of silencing and marginalization;" and how this 
approach aimed to treat the damaging impact of colonisation on the colonised and their existence (p. 96).

\section{White Control}

Jane Harrison's Stolen, presents a series of scenarios that show the complex connection between race and space. This bilateral relationship used in the colonisation of the Aboriginal Australians rests on a philosophy of cultural conformism and assimilation, a notion that is propagated as being good for the nation but covertly operating "to maintain white control over national space" (Miller, 2017, p. 366). The nation being structured around White culture imposes on Aboriginal Australians to exist as objects "to be moved or removed according to the White national will" (Hage, 1998, p.18). These strategies of control appear to challenge racism, while in effect, such practices solidify white power.

The Australian government implemented colonial legislations that enforced discriminatory practices which defined the lives of Aboriginal Australians. Aboriginal youngsters were forcefully dismembered from their families and sent to welfare institutions. They became known as the Stolen Generation. Carmel Bird (1998) in The Stolen Children, Their Stories wrote:

Nothing is more valuable to us than our children, nothing so irreplaceable, so precious, so beloved. ...The stories of these children ... ring with the notes of darkest nightmares. ... How must it be 
then, to be such children, stolen children? How must it be to be children who have been snatched from their mothers and systematically stripped of culture, language, rights and dignity? ... children who grow to be adults within the very society that visited these crimes upon them (p.19).

Jane Harrison depicts these controlling practices in her performance text Stolen. As a Murawari, Harrison curated the black experience of Aborigines over the course of six years. The minimal stage setting, the five old iron institutional beds that look like bars of a prison cell, metaphorically signify the lack of rights and the loss of their culture and language- a life devoid of meaning. The five actors: Jimmy, Ruby, Shirley, Sandy and Anne are all stolen children.

Shirley, in the scene titled "Adult Flashes" is thinking on the stage about the past. She waves a hand-knitted jumper from the front centre stage at the audience:

SHIRLEY: Kate, I held you once in my arms and I didn't get to hold you another twenty-five years. ... I didn't get the chance to be a mother to Kate and Lionel ...But this time, this time ... [She wipes away a tear.] This time I am going to hold my baby and never let her go. (p.2 my emphasis)

The repetition rehearses the difficult emotion of reckoning with the primary trauma surrounding the painful loss of her young indigenous child. It is also a summative statement asserting the 
co-responsibility in shattering frames that maintain unequal social divisions between colonial settlers and Indigenous Australians.

The unequal power dynamics of settler colonialism on Aboriginal Australians are re-enacted in Sandy's Story of the Mungee.

SANDY: Do you wanna hear the story of the big bad Mungee? My grandfather told me this. A long time ago there was no darkness. The yurringa [local dialect for 'sun'] -

SHIRLEY: But you are not allowed to say that...

SANDY: The Mungee got so hungry that he came and snuck into his peoples's camp and stole one of the children! Then he ate him up! Munch munch munch - ...The mob were frightened.... The Mungee's stealing our babies', they cried to the elders. ... We can't catch him because we can't see him in the dark!.... they threw magic powdered bone all over him.... The Mungee was turned into a pale skin and that was his punishment. He would never be able to sneak into the camp to steal the children because he would be seen. And the people would know. And the people would never forget. ... [To Ruby, very softly] ... but remember, it's not the dark you need to be afraid of. (p.11 my emphasis).

The scene demonstrates the settler-colonial violence in Aboriginal societies in Australia. Harrison is hinting at the core concept of Négritude of "reclaiming one's past" (Said, 1993, p.275), the ritual container scene references local Aborigine dialect "yurringa"(sun) and "barra" (kangaroo). The scene further 
alludes to the principles of Négritude by creating the act that allows both audience and performers to contemplate assessing the relationship between the "colonizer and the colonized" (p.275). Through the use of magic and ritual, the scene is proposing "transitional justice" where the White settler is punished for the mass violence against Indigenous people (McEvoy and McGregor, 2008, p.2-3). The camp is a neutral space for Indigenous people and serves as a space within which the presentday Aborigine stolen generation can rehearse their past practices of cultural sovereignty. The theatre stage is a significant vehicle used by the playwright to capture the possibilities of justice around the conflicted Aborigine-White Australian relations in public space. Harrison, in this scene, maintains the Aboriginal traditions and language as a means of cultural revival.

\section{Motherhood in Black and White}

The play unfolds a series of confrontations. Shirley, now an adult, continues to suffer the consequences of being a stolen child and at the same time, lives the pain of having had her two children forcefully removed from her when they were young. The stage directions in "Shirley's Memories" says "SHIRLEY, as a child, clutches the one remaining physical link to her family - an old sepia photo album. As she traces her finger over the figures,.... The chorus crowd around and try to snatch the album from her" (Harrison, Stolen, p. 17). The semiotic reference to her family 
represented as an album, is symbolic of familial ties being torn; the visual depiction of the child's traumatic memories of being cut off is a painful rehearsal on stage. Shirley in "Shirley Knits for Her Family" addresses the audience: "After all these years to get used to it, it still hurts" (p.19). Once again, the power imbalance between Aborigines and White Settlers is witnessed in this scene through the semiotic reference. Shirley has not been able to locate her stolen children since 1966. The painful search for her children is captured in "Shirley Never Gives Up Searching," on the phone she is met with a polyphony of voices:

SHIRLEY: Yes, I'm ringing about one of my children, Lionel, who was taken from me in 1966 when he was just two years old. Why was he taken? Well, you tell me...

VOICE: I'm just following up on the hope that you might know of an Aboriginal boy who was adopted or fostered in 1966 by a white family in your area. His name was Lionel...

SHIRLEY: Put me on hold... [She laughs bitterly.] You people have been putting me on hold for twenty-seven years... (p.21-22).

The painful ordeal is experienced by another Aboriginal mother in the play; Jimmy's mother. Jimmy never reunites with his mother because he is repeatedly informed, she is dead: "Fuck me dead. [He laughs.] So my mother's not dead- those lying bastards. ... They took us to Cranby Children's Home. ... they lined us kids all up and one was chosen by this white family... So I've 
got a mother, eh...? Fuck me! Willy Wajurri and I've got a mother! (p. 27).

Jimmy finally locates his mother after twenty-six years; he struggles with his emotions because he finds it difficult to meet a mother whose motherhood he has never experienced. Unfortunately, his mother Nancy, dies before he gets to meet her. Disappointed, Jimmy commits suicide in a prison cell where he had been detained for getting entangled with a White Australian who called him "bloody nigger" and a "dirty black bastard" (p.3233). Alienated in a prison cell, the taking away of his black soul through suicide becomes his weapon against racism and forced removal. Jimmy has been on the run all his life, a man with no land - a perpetual nomad. The cell is yet another signifier of the white spatial control imposed on blacks. Négritude, from Césaire's perspective, according to Ahluwalia (2002), equates colonialism with racism; it "dehumanises and objectifies the colonised" (p.22). Jimmy's humanity is negated by the cell ward, but his humanity is empathized with by the modern-day white audience- symbolic for the coloniser.

The experience of black motherhood is contrasted in the play against white motherhood. Assimilation, enforced by the Australian government placed the stolen children in foster homes with white parents. Anne, the fourth of the five children in the play, is chosen for being a half-caste. As her story is narrated, the playwright projects the image of the white parents as shadows on 
the stage. Anne is told by the parents that she was adopted from the Cranby Children's Home. This is easily accepted by Anne. Yet, the white parents are hesitant to inform her that she has an Aboriginal mother:

MOTHER: No one need ever know.

ANNE: I know. And I want to know why you didn't tell me about this before.

MOTHER: [sobbing] The shame...

ANNE: [angrily] You should be ashamed-

FATHER: We've nothing to be ashamed of. We've always acted in your best interests! Look what you've done to your mother! (p.14)

Anne as a teenager is facing a crisis, the scene depicts the white family's cultural arrogance and reinforces at the same time, the intercultural collision of two worlds symbolised by the white family and Anne the Aboriginal child both within the same room, the girl's bedroom; ultimately the scene is reinforcing the notion of "white spatial control" (Miller, 2017, p.367). It simultaneously suggests that "Western provisions are desirable and that Aboriginal people cannot provide for themselves" (p.368). Mother in the play says, "We'll give her the best of everything...a good education...And a good upbringing... (p.7). The dualistic structure which seeks to negate the white control cannot repudiate 
it because Anne, has seen too much of the good that Western culture can offer.

The playwright represents in this scene indigeneity within a metaphorical colonial context reflecting the Australian Government's assimilation process often working "to justify white superintendence of the land and non-white others" (p.367). The Father, representative of the authoritative body in the state, equally affirms that "We've always acted in your best interests!" (Harrison, 1998, Stolen, p.14). This paper further argues that this scene, is one of the most significant episodic structures created by the playwright as the characters, both Aboriginal Australians and White Australians, are present together in an attempt to assert their cultural endurance and emphasize white dominance. The scene exposes the lack of ethical responsibility of White Australia towards the Aboriginal community within contemporary Australia. This, no doubt, is reinforced throughout the land by the white settler media constructions and government policies. Valerie Babb (1998) explains that national texts have aided in "the construction of whiteness as an ideology, a system of beliefs privileging those with white skin” (p.47). Mary Casey (2013), traces a similar pattern in performance where indigenous performers are framed either in "the myth of the doomed race" or depicted as "savages lower on the Social Darwinian hierarchy of cultures and peoples" (p.64). This is reflected in the Mother's refusal to tell Anne she is Aboriginal because of "The shame..." 
(Harrrison, 1998, Stolen, p. 14). The intercultural theatrical scene depicting the Aborigine-European Settler conflict opens the dialogue for White modern-day Australians to explore and take seriously the process of addressing past trauma and redress the Aborigine demands for restitution. Négritude has been criticised for reinforcing the notions of white supremacy which it sought to challenge, however, this paper argues that in this scene, while the playwright reinforces the white privilege, it also pinpoints that the destinies are inseparable. The scene extends to show that both the white family and the Aboriginal family are ready to denounce Anne should she choose one family over the other putting her at the crossroads as she is obligated to choose between a future that guarantees her welfare and a heritage that will eventually ruin her:

FATHER: [off] You're one of us, Anne -we've brought you up as one of our own.

MOTHER: [off] We've given you everything - a home, an education, a future.

FIRST BLACK VOICE: [off] But we're your real family. (p.28) Anne, tormented and confused a few scenes later addresses the audience by voicing their aspirations: "S'pose you want a happy ending from me. You blackfellas want me to be reunited with my family,... You whitefellas want my adopted parents to become loving and tolerant of my black family. ... What about me? What do I want? (p.34). Although like Senghor, Harrison's objective is 
to vindicate the black people's culture, it may be perceived that the play is echoing the colonialist's denigration of black Aborigine heritage, hence making the already deprived, more invisible. It is within this schism that Harrison constructs a postcolonialist discourse amidst the noisy battleground and deconstructs the racist myth like the Négritude predecessors, through the contestation of colonial discourse enacted in the dialogue of Father, Mother and Black voice and the reclaimed value of the Aborigine black people symbolized in Anne's autonomous identity.

The contrast between white motherhood and black motherhood in the play, is a comparison focused on the theatrical representation of otherness. The difficulty of black motherhood in white Australia can be traced across the entire play. Stolen provokes the audience to witness for themselves the culture that discriminates on the basis of race and shifts the audiences' attention from critiquing the black mother's actions to reflect on the powerlessness of the mother to protect her children and herself from experiencing the effects of racism. Denied voice and authority, the Aboriginal mother is forced to give up her child. The mother child dynamic in Stolen is explored in its normal sense between the white mother and the adopted Aborigine child Anne and in its dysfunctional form between the black mother and her stolen child. The white mother is depicted as the ideal mother. The idealistic view of motherhood for the black Aborigine mother 
is diffused in the scene "Shirley's Come Full Circle" where Shirley is meeting her daughter Kate and her newly born granddaughter at a hospital. Shirley overreacts when the nurse comes to take the baby so Kate can shower: "I'll take that baby now', and I said, 'No, you won't', and I burst into tears like an old fool" (Harrison, 1998, Stolen, p.35). The hospital is another symbol of spatial control where the traumatic impact of racism is triggered as a reminder of the inability of the black mother to protect her daughter and granddaughter, exemplifying all the "dark mothers who live in fear" (Meier, 2000, p.121). The hospital white walls are moreover contrasted against the black souls. The childbirth scene of a new grandchild is a metaphorical celebration of Blackness and regeneration-a renaissance of Aboriginality.

\section{Battered Children}

Ruth is one of the five Aborigine children in the foster home. She signifies the staging of "trauma of sexual child abuse" (Hacking, 1991, p.255). As a child, Ruth is sexually abused and is silenced by her transgressor. After each abduction, Ruth would sing to a rhythmic beat with the other children in the foster home. Porges (2011) explains that rhythm-based behaviors have a healing effect on people who have gone through adverse experiences, the functioning happens through the undamaged regions of the brain. Supporting this explanation, van der Kolk 
(2015) highlights that rhythm-based activities reawaken feelings of pleasure dulled by prolonged trauma exposure. This indirect reference to music therapy for trauma survivors is disguised by Harrison on the stage as child play. van der Kolk and van der Hart (1995) additionally point out that "traumatic memory remains unaffected by time and cannot be recounted verbally." (p.163)

As an adult, Ruth is emersed in a number of experiences that lead to her re-experiencing the traumatic sexual abuse. According to Christina Wald (2007), because of the overwhelming suddenness of the traumatic moment, it is often not fully grasped but only "lived through" at the time of its occurrence. The psychic wounding is described by Harrison in the stage directions: "RUBY stands there, copping abuse... She falls on the floor, where she huddles, rocking. We hear the sound of an ambulance siren" (Harrison, 1998, Stolen, p.24-25). Ruby is experiencing flashbacks and triggers of the memory of the abuse, which ultimately means that traumatization sets in despite the belatedness. Wald (2007) emphasises that trauma cannot be narrated, it is not knowledge possessed by the person who experiences the trauma, but it is the experience of trauma that possess the subject and hence the psychic experience returns. Herman (1992) argues that the traumatic experience is encapsulated in the body, hence the trajectory is that "the victim's body becomes a body of evidence" (37-42). The emotional truth of the memory is what impacts the reality of the victim's present. 
The brief stage directions partially address Ruby's dilemma. The play further reveals the incongruencies between the ideals an Aborigine child has of their future and the reality of their black existence. Ruby's experience as a maid within a white family's home is a contrast of the loving home ideal and its insular quality against the disharmony of power of a racial system. Unlike Wesley Enoch's play Black Medea, another Aboriginal play, Harrison's black Aborigine children in Stolen do not get the gift of being killed at once by the black mother to ensure their safety and happiness, but rather, the black children are left over time to endure the torture and the wrongs of racism. It can be argued that the playwright deliberately refrains from rescuing her characters from the fate of existing in a world that does not value their existence to show how they were ostracized by society. Négritude here is reflected in how the talent of these children as adults is unacknowledged and unrecognised by a nation that they are inherently part of.

\section{Negro Gift of Laughter}

The third key transformative point in the play is in "Cleaning Routine 2", the five children in the foster home, as they begin their cleaning routine, start to dance and sing to the tune of "We're happy little Vegemites"” (p.16). The laughter in the play is deeply ironic. The scene is terse and the dialogue is compact: 
RUBY: [sarcastically] And what are you going to be when you grow up?

The children call out together and mime the actions to go with the profession.

CHILD: A doctor.

AUTHORITY FIGURE: No.

CHILD: A teacher.

AUTHORITY FIGURE: No.

CHILD: A domestic?

AUTHORITY FIGURE: Yes!

CHILDREN: We're training to be cooks-yes, yes

We're training to be cleaners-yes

And we'll earn much less

Because we love to work like slaves, we all adore to work like slaves. It puts a rose in every cheek.

The children slap each other's faces. (p.17-19)

The dark humour displayed in children singing and dancing on the stage exposes the role of foster homes as authority figures that contribute to the system of racism. The scene is a mix of joy and pain, of innocent children and racist Australia, the children speak of the unspeakable. The play painfully critiques the povertyridden reality of Aboriginal children, their bleak future as slaves, 
and the menial domestic service jobs made available for humans of colour. The call and response format resembles an "antiphonal interplay" (Meier, 2000, p.133) a technique similar to that of music to counterpart the seriousness of critiquing the lack of opportunity, education and employment for black people. It is also a brief indirect commentary about the ineptness of the Aboriginal people in solving their own problems without involving the Australian government, that is not to erase the audiences' gaze from the racist colonial practices, but it is a call through the play for confronting problems.

\section{Strategies of Resistance- Aboriginal Theatre a Vehicle for}

\section{Change}

The play, is written and produced for Black Aboriginal Australians and White audiences, it echoes African American slave narratives and the experiences of blacks under colonial conditions and in postcolonial nations as they struggle to bridge the rifts of racism and attempt to alleviate the suffering in their lives. Joyce Meier (2000) emphasizes that "these plays become a powerful vehicle for change because theatre provides a potential space for audience identification, on the parts of both blacks and whites, with the seemingly inescapable dilemmas these [stage characters] face" (p.135). The disjunction between ideal and reality is at the heart of this play. Marc Maufort (2001) explains that "Australian aboriginal playwrights wish to offer a new 
perspective on their forgotten history, thus undermining the biased vision of white settlers" (p.8). White Australians writing about the experiences of black Aborigines is tumultuous, writing about identity politics is in itself a power struggle.

The minimalist stage setting of five iron institutional foster care beds on the stage is a deliberate approach by director Wesley Enoch, to focus the audiences' attention on the emotional and psychological re-enacting of aboriginality and of contemplating the present within the framework of Négritude of "reclaiming one's past" (Said, 1993, p.275). The seemingly modern basic stage setting transports audiences beyond the stage to consider life before white Australia. In accepting the theatrical conventions, audiences are encouraged to engage in tracing the trauma of abuse reflected in the innocent child play, invited to assess the meanings of being black and being white which this paper argues is a subtle nod to Négritude extended in Anne's scene 'To Tan or Not to Tan', experience the descent into madness with Ruth and live the emotional heartbreak of black motherhood. The play presents aboriginality in its crudest form.

Furthermore, Harrison's play challenges the culture of forgetfulness a "politically charged strategy that has characterized settler history" (Thomson, 2001, p.23). Stolen serves as a valuable rewriting of Aboriginal Australian history and a documentation of the black experience in a society dominated by white supremacy. According to Emma Hughes (2015), "Audience members who 
watch Stolen collaborate in the remembrance of real and traumatic events" (p.33), as the play is based on the lived experiences of Aboriginal Australians’ race-based assimilation.

\section{Only an Aborigine will be able to explain an Aborigine's Black Experience}

Challenges to the stereotyping of black people and indigenous societies is a corner stone in the Aboriginal Australian struggle for self-assertion and recognition. Contesting the image of the primitive man and restaging the power relations between Indigenous Australians and the European Settlers to contemporary audiences heightens the white audiences' awareness of the need to re-negotiate the past and for black audiences to negotiate the present as a continuum of their fight for survival. The play, disrupts audiences' expectations of heritage and cultural authenticity as they witness presentations of the self on the theatre stage. The power dynamic between Indigenous performers and a non-Indigenous audience is a compelling experience, one that requires a decoding of the unfolding dialogue and the projected politics of racism. The central tension rises from the theatrical space used to challenge the limits of the settler- colonial subjects' attempts at eradicating the Aboriginal peoples, and consequently, this challenges the uni-directional flow of power and white cultural agency in settler colonial spaces. The use of a photo 
album and projected images by director Wesley Enoch, brings past racial abuse to haunt the stage.

Blacks have comparable experiences under colonisation and assimilation processes. Aboriginal Australians, similarly, have been forced to adopt the language of the oppressor inscribing the values and culture of the white man in their ideals. Harrison and Wesley Enoch understood that; there are clear resonances in their work of the Blackness of the Aboriginal identity. Stolen is structured in a manner that portrays how the Aboriginal identity responds to the world, and in particular, the way the stolen generation responds to racism and white supremacy. These racial binaries are reaffirmed through Négritude. Négritude was "contextualized against the general background of colonisation and the manner in which the African's very being was denigrated" (Ahluwalia, 2002, p.18). Isolated because of their colour, the founders of the Négritude movement, the enslaved Africans, and Aborigines all share the same fate. According to Pal Ahluwalia (2002), "[t]hrough négritude the colonised sought to reverse the representations ascribed to them, to turn those negative identities into positive images" (p.19). Stolen, in fact, does not particularly show positive images of Aborigines. Instead, the play is about being black, this is the epitome of its success. Stolen is preoccupied with the black experience within the Australian context. The dramatic text, has a strong element of resistance, a notion upon which Négritude is founded since its 
inception. The play depicts the characters of the five Aborigine stolen children as humans who experience pain and suffering as a consequence of racism and white spatial control in contrast to the identity which has been problematized within colonial discourse. Both Harrison's play and the Négritude movement work on reclaiming the past heritage of being black. Stolen at the same time, highlights the ambiguity experienced by modern-day Aborigines who underwent the assimilation process, the character, Anne, in the scene "To Tan or Not to Tan" expresses her emotional turbulences and psychological confusion of being "[n]ot yet white, no longer wholly black" (Fanon, 1986, p.138). This complex scene further indicates that past injustices may not be possible to heal, but the way forward for the new generation requires different solutions. The scene indirectly hints at redress. Frantz Fanon (1986) points out that not belonging in either culture, leads to a sense of alienation which ultimately leads to the rejection of the two, the solution is to seek that which is universal (p.197). The hybrid identity encapsulated in Anne's character, in Stolen, according to the notions of the Négritude movement, result out of the interaction between the black and the white.

The play further creates the space necessary for people of colour to display their perspective on the black and white relationship. Stolen written and produced by Aboriginal Australians acknowledges the Aborigine heritage and its success offers blacks a cause of pride while at the same time, allowing white audiences 
to recognise the value of the black person. Senghor, in his call for Négritude never denounced colonialism, he recognised that it played an essential role in forging a national identity. It further evolved to constitute "an ideology for unity, economic development and cultural growth" (Markovitz, 1969, p.49). Césaire, however, unlike Senghor, denounced colonialism and sought the Négritude movement to express notions about black lives and values. Harrison's perspective in Stolen, encourages the Aboriginal identity to transcend the assimilation phase imposed by the colonial European settlers and to develop a decolonised national culture which begins by decolonising the mind.

\section{Conclusion}

Stolen is written from an Aboriginal Australian perspective that finds expression not in the content, but in the effect the writing has on the reader. The theoretical lens applied to Harrison's playtext, which rests on key Négritude scholar Léopold Sédar Senghor's notions, is a form of anti-colonial resistance and a fight against racism and oppressive regimes. The play, following the aims of the founding fathers of the Négritude movement, is an attempt to come to terms with the black experiences of denigration and degradation in a white-controlled space. Neither the Négritude movement nor Stolen are able however to deal with the realities of racism against blacks nor offer solutions to their underdeveloped conditions and poverty. Négritude's call for a 
return to the past and African roots was delusional, and similarly, the Aboriginal notion of searching for the ideal home is a cause for suffering as they discover that their conditions and native land is despotism without European modernity and white power. Négritude is considered as the decisive element in the evolvement of the black identity and its coming to consciousness, it is what helped black people assert their Blackness not only because of racism and white supremacy but because it was necessary to ensure the black individual whether African or Aborigine continued the process of identity formation as it is according to Ahluwalia (2002) a key phase in the arduous struggle towards decolonization. 


\section{Works Cited}

Ahluwalia, P. (2002). Politics and Postcolonial Theory: African Inflections. Routledge.

Babb, V. (1998). Whiteness Visible: The Meaning of Whiteness in American Literature and Culture. New York: New York University Press.

Barrend van Dyk, V. (1970). The African Image in the Works of Senghor. Cape Town: Balkema.

Bell, D. (2010). Oxford University Press.

Bird, C. (1998). The Stolen Children, Their Stories, Human Rights Vommiddion. Sydney: Human Rights Commission Random House.

Bird, G. K. (2019). Foundations of Just Cross-Cultural Dialogue in Kant and African Political Thought, International Political Theory. Palgrave.

Casey, M. (2013). Colonists, Settlers and Aboriginal Australian War Cries: Cultural Performance and Economic Exchange. Performance Research: A Journal of the Performing Arts, 18(2), 56-66.

Casey, M. (2004). Creating Frames: Contemporary Indigenous Theatre 1967-1990. Brisbane: Queensland University Press.

Enoch, W. (2007). Black Medea. Contemporary Indigenous Plays. Strawberry Hills: Currency Press.

Fanon, F. (1965). The Wretched of the Earth. London: MacGibbon and Kee.

Fanon, F. (1986). Black Skin, White Masks. Gardners Books. 
Hacking, I. (1991). The Making and Molding of Child Abuse. Critical Inquiry. The University of Chicago Press, vol.17, no.2, 253288. https://www.jstor.org/stable/1343837

Hage, G. (1998). White Nation: Fantasies of White Supremacy in a Multicultural Society. . Sydney: Pluto.

Harrison, J. (1998). Stolen. Playbox and Ilbijerri, in association with, the Melbourne Festival.

Howe, S. (1999). Afrocentrism: Mythical Pasts and Imagined Homes. London: Verso.

Hughes, E. (2015). Maternal Practice and Maternal Presence in Jane Harrison's Stolen. Outskirts, 33, 1-17.

July, R. W. (1987). An African Voice: The Role of Humanities in African Independence. Durham: Duke University Press.

Markovitz, I. (1969). Leopold Sedar Senghor and the Politics of Negritude. Heinemann Educational.

Maufort, M. (2001). Forging an Aboriginal Realism: First Nations Playwriting in Australia and Canada. In M. Maufort, \& F. Bellarsi, Siting the Other: Re-visions of Marginality in Australian and English-Canadian Drama, Brussels: Peter Lang, 7-22

McEvoy, K., \& McGregor, L. (2008). "Transitional Justice From Below: An Agenda for Research, Policy and Praxis?". In K. McEvoy , \& L. McGregor, Human Rights Law In Perspective: Transitional Justice From Below, Grassroots Activism and the Struggle for Change. Oxford, Portland: OR: Hart, 1-25.

Meier, J. (2000). The Refusal of Motherhood in African American Women's Theatre. MELUS, 117-139. 
Miller, B. (2017). "Come be off with you": White spatial control in the representation of Aboriginality in Early Australian Drama. The Journal of CommonWealth Literature, 365-381.

Osofisan, F. (1999). Theater and the Rites of "Post-Negritude" Remembering. Research in African Literatures, Indiana University Press, vol.30, no.1, 1-11. https://www.jstor.org/stable/3820469

Porges, S. (2011). The Polyvagal Theory. New York, NY: W. W. Norton and Co.

Ripstein, A. (2009). Force and Freedom: Kant's Legal and Political Philosophy. Cambridge: Harvard University Press.

Said, E. (1993). Culture and Imperialism. Alfred A. Knopf Inc.

Thomson, H. (2001). Aboriginal Women's Staged Autobiography. In M. Maufort, \& F. Bellarsi, Siting the Other: Re-visions of Marginality in Australian and English Canadian Drama, Brussels: Peter Lang 23-37.

van der Kolk, B. A. (2015). The Body Keeps the Score: Brain, Mind, and Body in the Healing of Trauma. London: Penguin Books.

van der Kolk, B. A., \& van der Hart, O. (1995). The intrusive past: The flexibility of memory and the engraving of trauma. In C. Caruth (Ed.), Trauma: Explorations in memory. Johns Hopkins University Press, 158-182.

Wald, C. (2007). Hysteria, Trauma and Melancholia: Performative Maladies in Contemporary Anglophone Drama. Palgrave Macmillan. 
التمثيل المسرحي للزنوجة:السكان الأصليون وهيمنة ذوي البشرة البيضاء في

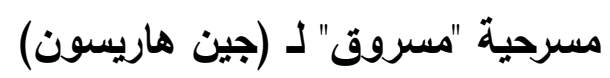

ملخص من لرن

تكثف العروض المسرحية القديمة التي تتناول قضايا السكان الأصليين في المسرح

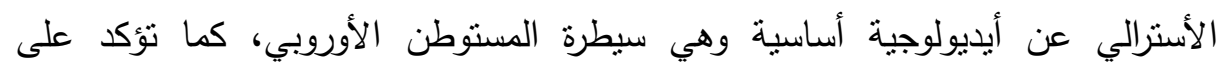

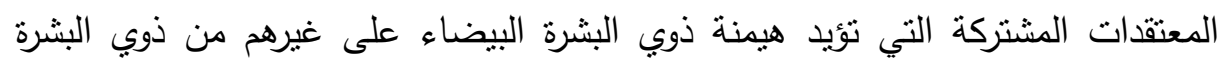

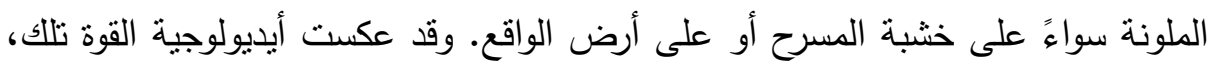

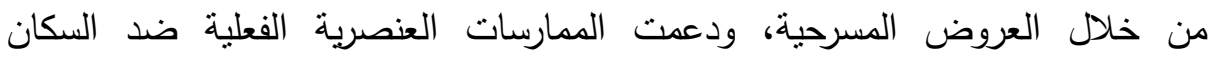
الأصليين (الأبورجيين) في شتى مجالات الحياة اليومية في أستراليا. فالعروض المسرحية المبنة في ذلك الوقت لم تكن مجرد أعمال فنية تعكس الظروف المحلية آنذاك وحسب، ولاتبات ولكنها

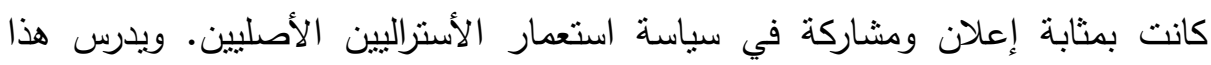

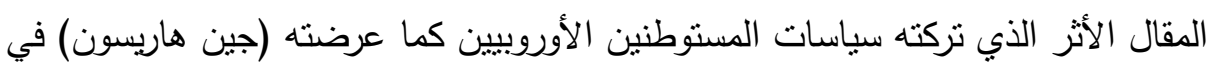
مسرحيتها "مسروق" Stolen (991) (191). حيث تستعرض هذه الورقة البحثية التداعيات

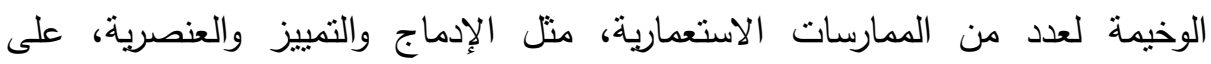

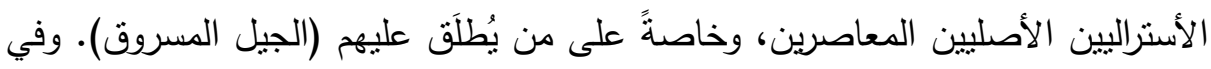

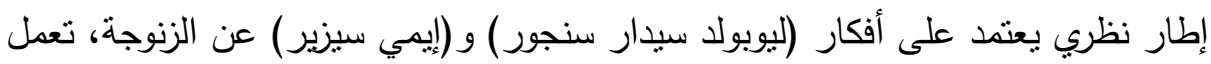
هذه الدراسة على تحليل التمثيل المسرحي للسود والسكان الأصليين وهيمنة المستعمرين البيض كما تعرضه المسرحية. كما يسعى التحليل أيضًا إلى بيان كيفية تتاول الكانبة

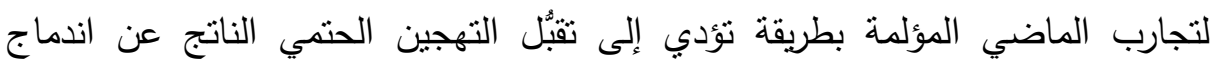

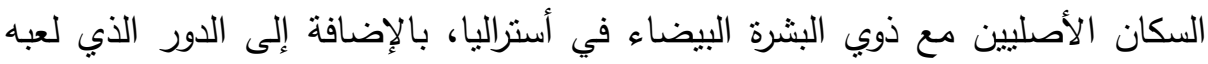

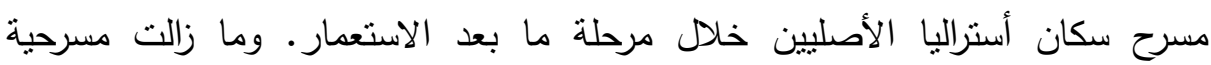

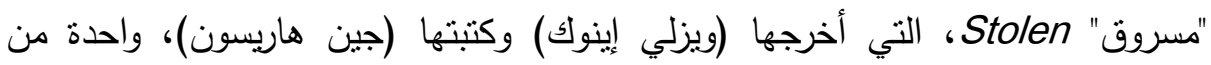

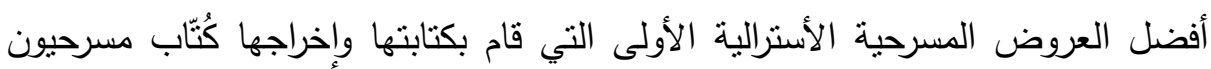
ينحدرون من نسل سكان أستراليا الأصليين. كلمات مفتاحية: الزنوجة، مسرحية "مسروق" Stolen، مسرح سكان أستراليا الأصليين، جين هاريسون، هيمنة ذوي البشرة البيضاء

(Staged Representations of Négritude ...)Dr. Rania Mohamed Rafik 1909 